\title{
Political Instability and the August 1998 Ruble Crisis
}

\author{
Tatiana Fic \\ National Bank of Poland \\ Omar Farooq Saqib \\ State Bank of Pakistan
}

\begin{abstract}
The main objective of this study is to highlight the importance of political instability, defined as frequent changes in and of government, in undermining the Russian exchange rate based stabilization program of the 1990s. The empirical evidence supports the significance of political instability along with economic fundamentals in determining Russian real effective exchange rate and exchange market pressure, used as a proxy to the crisis.
\end{abstract}

- JEL classification: F31, C13

- Keywords: Currency crises, Economic fundamentals, Political instability

\section{Introduction}

In its early years of transition and after experiencing a mini currency crisis, ${ }^{1}$ Russia in consultation with the International Monetary Fund implemented an exchange rate based stabilisation programme in 1995 with the objective of achieving single-digit inflation, financial stability, and growth. From June 1995 to redenomination of ruble in January $1998,{ }^{2}$ the management of exchange rate within

\footnotetext{
*Corresponding address: Fic, Tatiana, Macroeconomic Projections Division, Head of Department of Macroeconomic and Structural Analyses, National Bank of Poland Swietokrzyska 11/21, 00-919 Warsaw, Poland. Tel: (+48)22 6531315, Fax: (+48) 22 8269935, E-mail: Tatiana.Fic@mail.nbp.pl; Saqib, Omar Faroop, Senior Research Economist, Research Department, State Bank of Pakistan, I. I. Chundrigar Road, Karachi 74000, Pakistan. Tel: (+92) 21 2453808, Fax: (+92) 21 9211488, E-mail: omar.farooq@sbp.org.pk (c)2006-Center for International Economics, Sejong Institution, All Rights Reserved.
} 
Figure 1. Nominal Exchange Rate, CPI Inflation, Oil Price, Real Interest Rate: 1994Q12001Q4
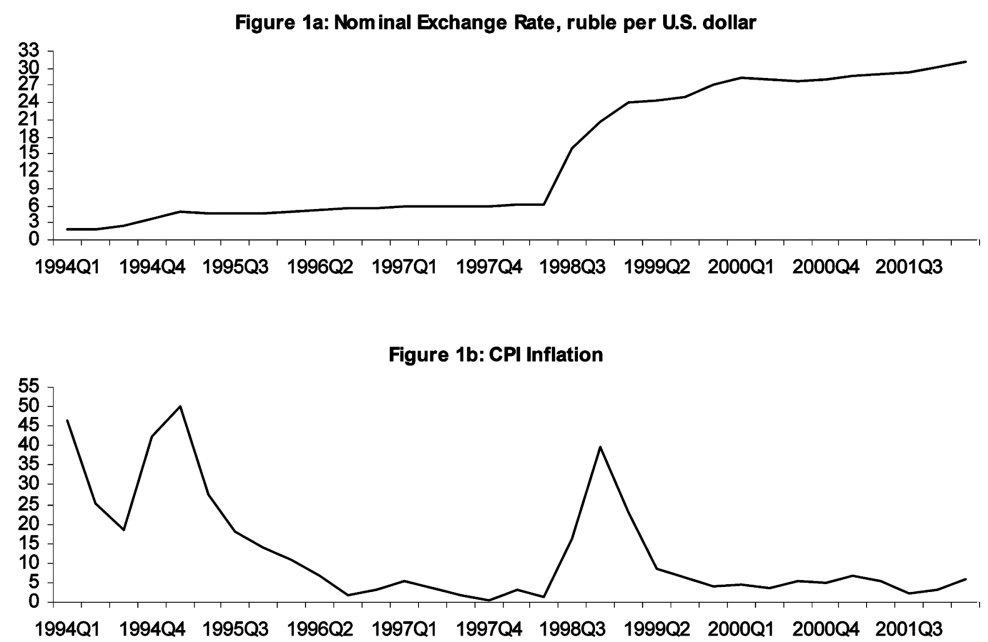

Figure 1c: Oil Price; U.K. Brent, U.S. dollar per barre
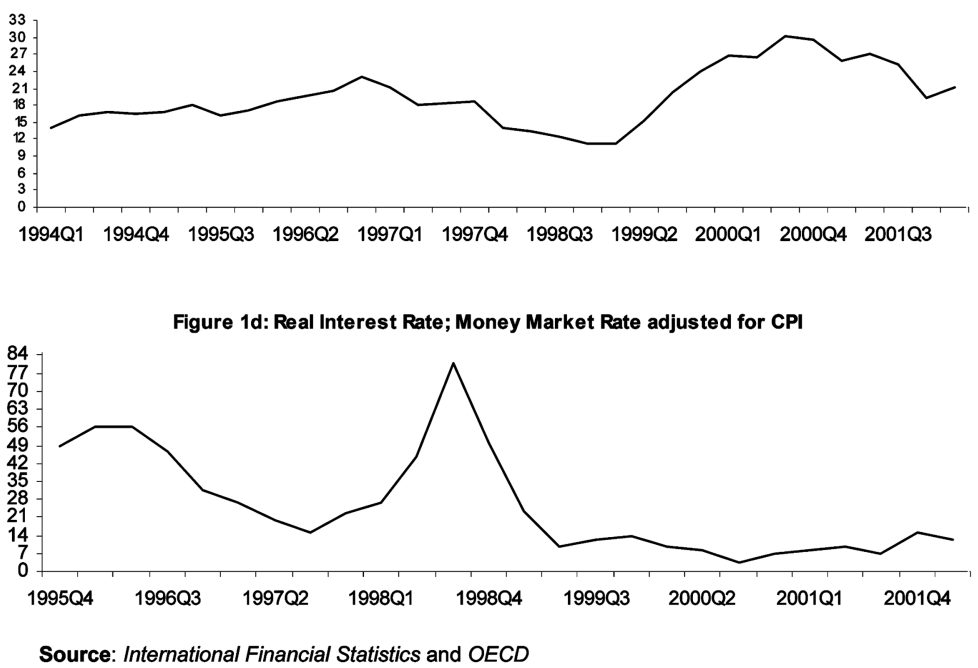

a band and tighter monetary stance resulted in low prices. A combination of low inflation, high interest rates, and rising and relatively stable oil price until mid 1997 strengthened the demand for ruble (Figure 1). These developments signalled stability of the economy and opened the way for 'euphoric' capital inflows during

${ }^{1}$ In October 1994, ruble depreciated by nearly 20 percent.

${ }^{2}$ In the redenomination, three zeros were slashed from the ruble. 
1996-97.

Two exogenous shocks ended this time of euphoria: successive devaluations in a number of East Asian economies in the second half of 1997 and sharp decline in oil price from January 1998 onwards. The first shock prompted capital outflows during late 1997 from the Russian economy. The Central Bank of Russia was initially able to defend the resulting pressure on ruble but then it was forced to finance the (persistent) budget deficit by redeeming maturing treasury bills on behalf of the government. ${ }^{3}$ The weakness in oil price that was visible in late 1997 turned into sharp decline by mid 1998. The Brent in London was close to $\$ 17$ per barrel in January 1998 but went below $\$ 12$ per barrel by August $1998 ;{ }^{4}$ causing further deterioration in investors' confidence and the second wave of capital outflows began in May 1998 that eventually resulted in the crisis of ruble in August 1998.

Although the pegged exchange rate based stabilisation program achieved its objective of low inflation, there remained no improvement in Russian fiscal imbalances and internal and external obligations; along with their un-sustainability due to sluggish economic growth. As these fundamentals are one of the leading predictors of currency crises, ${ }^{5}$ Russian economy remained highly vulnerable throughout the period of stabilisation program. In this respect, therefore, Russian crisis of August 1998 was standard and does not offer new insights.

If we focus, however, on the political realities of those times, there is considerable room for an alternative explanation of the crisis. In particular, we argue that much needed structural and policy reforms to make Russian markets and institutions compatible with those of free-market driven international standards were eschewed by a remarkable political instability during the 1990s. Due to the frequent changes in and of government, the general political environment in Russia was not conducive for the implementation of coherent or consistent policies. This actually undermined the pegged exchange rate based stabilisation program and eventually culminated in the 1998 crisis.

Thus, the main objective of this study is to highlight the importance of political

\footnotetext{
${ }^{3}$ This resulted in increase of net credit to government by 14.7 percent in the last quarter of 1997 . [Dabrowski et al. (2001)]

${ }^{4}$ The figures on oil price are from International Financial Statistics Database. Russia relies heavily on oil and gas receipts for its foreign exchange earnings. As noted by Antczak (2001), a dollar decline in the price of oil barrel costs Russian exporters $\$ 1.2$ billion losses in revenue per year.

${ }^{5}$ See, footnote 7 for a parsimonious list of the leading predictors of currency crises.
} 
instability in determining Russian crisis; in particular, the role of frequent changes in and of Russian government during the decade of 1990s. In Section II we motivate this hypothesis by presenting an overview of the economic fundamentals and political realities of Russia. Section III outlines the empirical strategy to determine Russian real effective exchange rate and an index of exchange market pressure, both used as a proxy to the crisis. Section IV gives findings of the regressions. Concluding remarks follow in Section V.

\section{The Motivation}

Right from the launch of stabilisation programme in mid 1995 until the eruption of crises, Russian economy remained fragile due to its dismal growth rates with climbing internal and external obligations, and above all due to persistent and unsustainable level of budget deficit that accompanied inconsistent revenue collection. These fundamentals remained weak and highly crisis-prone from late 1996 onwards (Table 1 and 2). Thus, if viewed within the predictions of firstgeneration model of currency crises, ${ }^{6}$ this instability should hardly be a matter of surprise. Both at theoretical and empirical levels, the aforementioned fundamentals especially that of fiscal imbalances are thoroughly tested predictors of currency crises. $^{7}$

Therefore, we can hardly doubt that the policymakers, both domestic and international who remained involved in Russia during its transition and its exchange rate based stabilisation programme, were not aware of the growing vulnerabilities of the economy especially from late 1996 onwards. ${ }^{8}$ Arguing on the same line, some economists have noted that apart from fundamentals' weaknesses in the

\footnotetext{
${ }^{6}$ As observed by Desai (2000) and Kharas et al. (2001).

${ }^{7}$ Following the seminal work of Krugman (1979) and Obstfeld (1986), a fairly large number of empirical studies on the determinants of currency crises have emerged. Generally, they suggest GDP growth, budget deficit, domestic credit, external debt, real exchange rate misalignment, current account deficit, inflation, and foreign exchange reserve loss as the leading determinants of this financial instability. A parsimonious list includes Blanco and Garber (1986), Cumby and Van Wijnbergen (1989), Goldberg (1994), Pazarbaşıoğlu and Ötker (1997), Ötker and Pazarbaşıŏlu (1997), Frankel and Rose (1996), Klein and Marion (1997), Esquivel and Larraín (1998), Kaminsky, Lizondo, Reinhart (1998), Masson (1999), Rodrik and Velasco (1999).

${ }^{8}$ See, similar comments of Stanley Fischer, Deputy Managing Director of the International Monetary Fund at the time of Russian crisis, in Kharas et al. (2001: p.62).
}

${ }^{9}$ Lamfalussy (2000), Summers (2001), and Poirot Jr. (2001). 
Table 1. Key Economic Indicators, 1993-1999

(units as indicated)

\begin{tabular}{|c|c|c|c|c|c|c|c|}
\hline Indicators & 1993 & 1994 & 1995 & 1996 & 1997 & 1998 & 1999 \\
\hline Growth $^{\mathrm{a} /}$ & -8 & -12 & -4 & -3 & 1 & -5 & 5 \\
\hline Unemployment $\mathrm{t}^{\mathrm{b} /}$ & 5.7 & 7.5 & 8.9 & 9.9 & 11.3 & 13.3 & 12.3 \\
\hline Wages $^{\text {c/ }}$ & 822.10 & 255.87 & 142.18 & 64.77 & 23.69 & 15.32 & 54.74 \\
\hline Revenues $^{\mathrm{d} /}$ & 14.9 & 14.2 & 12.7 & 11.5 & 12.0 & - & - \\
\hline Domestic credit ${ }^{\mathrm{e}}$ & $\begin{array}{c}44.45 \\
(25.91)\end{array}$ & $\begin{array}{l}193.64 \\
(31.70)\end{array}$ & $\begin{array}{l}363.67 \\
(23.60)\end{array}$ & $\begin{array}{l}539.29 \\
(25.13)\end{array}$ & $\begin{array}{l}659.25 \\
(26.59)\end{array}$ & $\begin{array}{l}1109.11 \\
(41.13)\end{array}$ & $\begin{array}{l}1487.20 \\
(32.72)\end{array}$ \\
\hline Budget balance $^{\mathrm{f} /}$ & $\begin{array}{c}-9.95 \\
(-5.80)\end{array}$ & $\begin{array}{l}-59.85 \\
(-9.80)\end{array}$ & $\begin{array}{l}-69.51 \\
(-4.51)\end{array}$ & $\begin{array}{c}-147.61 \\
(-6.88)\end{array}$ & $\begin{array}{c}-150.41 \\
(-6.07)\end{array}$ & $\begin{array}{c}-126.96 \\
(-4.71)\end{array}$ & $\begin{array}{l}-56.64 \\
(-1.25)\end{array}$ \\
\hline Current account $\mathrm{t}^{\mathrm{g}}$ & - & $\begin{array}{c}8.43 \\
(4.90)\end{array}$ & $\begin{array}{c}7.49 \\
(2.22)\end{array}$ & $\begin{array}{l}11.75 \\
(2.81)\end{array}$ & $\begin{array}{c}2.06 \\
(0.48)\end{array}$ & $\begin{array}{c}0.68 \\
(0.24)\end{array}$ & $\begin{array}{c}24.73 \\
(12.79)\end{array}$ \\
\hline $\begin{array}{l}\text { International } \\
\text { reserves }^{\mathrm{h} /}\end{array}$ & $\begin{array}{c}5.83 \\
(4.25)\end{array}$ & $\begin{array}{l}3.98 \\
(2.31)\end{array}$ & $\begin{array}{l}14.38 \\
(4.26)\end{array}$ & $\begin{array}{l}11.27 \\
(2.69)\end{array}$ & $\begin{array}{l}12.89 \\
(3.01)\end{array}$ & $\begin{array}{c}7.80 \\
(2.76)\end{array}$ & $\begin{array}{c}8.46 \\
(3.38)\end{array}$ \\
\hline
\end{tabular}

Source: Russian Economic Trends [Russian-European Centre for Economic Policy, London: Whurr Publications (various years)], International Financial Statistics, World Development Indicators

a/percent annual GDP growth rate; figures for 1993 and 1994 are reproduced from Giannaros (2000)

b/unemployment rate; percent per year

c/percent change over previous period

d/government revenue as percent GDP; reproduced from Lamfalussy (2000)

e'billions of ruble (figures in parenthesis are percent GDP)

f/billions of ruble (figures in parenthesis are percent GDP); figures for 1993 and 1994 are reproduced from Lamfalussy (2000)

${ }^{g}$ billions of dollars (figures in parenthesis are percent GDP)

${ }^{\mathrm{h}}$ billions of dollars (figures in parenthesis are percent GDP)

Table 2. Government Securities and External Debt

\begin{tabular}{c|ccc|ccc}
\hline Year & \multicolumn{3}{|c|}{ Government Securities $^{\text {a/ }}$} & \multicolumn{3}{c}{ External Debt } \\
\hline & $\begin{array}{c}\text { billions of } \\
\text { ruble }\end{array}$ & $\begin{array}{c}\text { as percent } \\
\text { M2 }\end{array}$ & $\begin{array}{c}\text { as percent } \\
\text { Revenue }\end{array}$ & $\begin{array}{c}\text { billions of } \\
\text { dollar }\end{array}$ & $\begin{array}{c}\text { Former Soviet } \\
\text { Union }\end{array}$ & $\begin{array}{c}\text { Russian } \\
\text { Federation }\end{array}$ \\
\hline 1995 & 73.7 & 33.4 & 36.7 & 120.4 & 103.0 & 17.4 \\
\hline 1996 & 237.1 & 82.2 & 93.4 & 125.0 & 100.8 & 24.2 \\
\hline 1997 & 384.4 & 102.8 & 123.5 & 123.5 & 91.4 & 32.1 \\
\hline $1998^{\mathrm{b} / \mathrm{c} /}$ & 436.0 & 118.3 & - & 158.8 & 72.0 & 86.8 \\
\hline
\end{tabular}

Source: Russian Economic Trends, Russian-European Centre for Economic Policy, London: Whurr Publications (various years)

${ }^{\mathrm{a}} \mathrm{GKO} / \mathrm{OFZ}$

${ }^{\mathrm{b}}$ Government Securities as of second quarter of 1998 (since the market was closed down on 14 August)

${ }^{c}$ External Debt as of 1 January 1999 and reproduced from Pautola (2000)

economy it was domestic structural and institutional weaknesses that eventually resulted in the August 1998 Russian crisis. ${ }^{9}$ Initial conditions in Russia at the time of the launch of stabilisation programme lacked necessary financial and legal 
infrastructure to comply with the newly acquired status of a free market economy. With this handicap, it was rather demanding to meet certain monetary and fiscal targets consistent with a pegged exchange rate policy. ${ }^{10}$ While we are in complete agreement with this consensus, we forward the hypothesis of political instability that actually undermined the much-needed structural and institutional reforms.

During 1990s the most pressing sphere of political instability in Russia remained the conflict of interests between the executive (the president and the ministerial cabinet) and the legislative (the parliament or the State Duma) bodies of the government. In this regard a major crisis emerged in October 1993 that led to the dissolution of the parliament. This was followed by parliamentary elections and a referendum on a new constitution in December 1993. As noted by Balino et al. (1997), the elections resulted in a parliament that was nearly evenly split between the reformers ( 30 percent), centralists ( 30 percent), and the nationalists ( 40 percent).

The referendum on new constitution resulted in the separate survival of the executive and the legislative with larger powers to the former in cabinet formation. The nearly evenly split parliament meant difficulties in the adoption of new reforms. The separate survival of executive and legislature meant their unaccountability to each other thus encouraging promotion of own interests at the cost of long-term conflicts and reduction in decision-making capacities of the state. The larger powers to the executive in cabinet formation led to frequent changes in and of governments.

The decade of 1990s was characterised by frequent changes in the Russian government. In the time period 1991-99, Russia had seven prime ministers and arguably more than seven governments. With the exception of Viktor Chernomyrdin's first stint none of the other Prime Ministers were able to keep their seats for more than a year. ${ }^{11}$ The apparently long tenure of nearly five years of Viktor Chernomyrdin was however marked by changes in the First Deputy Prime Ministers, Ministers, and Deputy Ministers by, mostly, the President of the Russian Federation. ${ }^{12}$ In addition to

\footnotetext{
${ }^{10}$ The only highlight in Russia's institutional and structural reforms besides liberalisation of its capital markets was the April 1995 Bank Law; it empowered the Central Bank of Russia for independent formulation and conduct of monetary policy and prohibited its direct lending to the government.

${ }^{11}$ The list of Russian Prime Ministers in the 1990s: (i) Yegor Gaidar: Nov 1991-Dec 1992; (ii) Viktor Chernomyrdin: Dec 1992-Mar 1998; (iii) Sergei Kiryenko: Mar 1998-Aug 1998; (iv) Viktor Chernomyrdin: Aug 1998-Aug 1998; (v) Yevgeny Primakov: Sep 1998-May 1999; (vi) Sergei Stepachin: May 1999Aug 1999; (vii) Vladimir Putin: Aug 1999-Dec 1999.

${ }^{12}$ See, Granville (2001) for a rather intriguing description of the different, sometimes surprising, dimensions of the personality of Boris Yeltsin as the President of Russia in the 1990s.
} 
this, there were two major reshuffles in the Prime Minister Chernomyrdin's cabinet: one in August 1996 and the other after just six months in March 1997. The changes in and of governments characterised the short tenures of other Prime Ministers as well. Moreover, abrupt and unexpected changes of the heads of important institutions, such as Central Bank or State and Federal Tax Services, remained relatively frequent. Appendix A provides a detailed overview of these changes.

Kounov and Sitnikov (1999) note that the process of budget adoption and execution involved the interests of executive and legislative bodies of the government at different levels, without any checks or controls to each other. Consequently, allowing the president to finance his re-election campaign from government funds and the parliament, by using its power over the budget adoption, to serve lobbyist interests. Furthermore, a third actor, the bureaucracy, greatly benefited from this conflict, since they remained unaccountable to the state organs in either the budget process or otherwise. Therefore, political instability and the immunity of bureaucracy from accountability provided accommodating framework for the promotion of a corruption culture.

Apart from the grass roots in the 1990s, corruption was rampant at the top level of business and political circles. ${ }^{13}$ In this regard, the special interest groups, popularly known as oligarchs, remained rather infamous for their role as tax evaders. According to the widely referred Corruption Perception Index of the Internet Centre for Corruption Research, Russia was ranked as 47, 49, 76, and 82 most corrupt countries in the world in 1996, 1997, 1998, and 1999 respectively. ${ }^{14}$ The perception of Russia as a corrupt country in the international media therefore greatly undermined the confidence of, especially, international investors.

In effect, the underlying rationale for forwarding the notion of political instability is that the frequent changes in and of government did not allow much room for the implementation of coherent or consistent policies, which exasperated the structural and institutional weaknesses in dire need of reforms. In fact, continuous political instability reflects in persistent budget deficits and for that matter external debts, low revenues, and low growth rates. ${ }^{15}$ Therefore, assuming then that the deterioration of fundamentals were the only determinant of ruble

\footnotetext{
${ }^{13}$ See, Levin and Satarov (2000) for a comprehensive overview of the corruption culture in Russia in the 1990s.

${ }^{14}$ Rank 1 is the least corrupt. See, http://www.gwdg.de/ for further details on the Corruption Perception Index.
} 
collapse would be a narrow approach.

\section{Estimation Methodology and Data}

In capturing the effects of political instability in undermining the Russian pegged exchange rate stabilisation programme, we use time series data and the estimation methodology is based on a general form of a short run model of the following specification: ${ }^{16}$

$$
\begin{array}{ll}
\Delta_{t}=\alpha_{0}+\alpha_{1} D 98+\beta C H G O V T_{t-i}+\delta \Delta y_{t-i}+ & \\
\sum_{k=1}^{m} \gamma_{k} \Delta x_{k, t-i}+\xi_{t} & i=1,2,3, \ldots
\end{array}
$$

In Equation (1), $y$ denotes the dependent variables. ${ }^{17} \mathrm{D} 98$ is the dummy variable assuming 1 in 1998 (the year of crisis) zero otherwise. CHGOVT, the variable of prime importance in this study, is the index of changes in and of government used as a proxy to the political instability (see, Appendix C for details). $x$ is $\mathrm{m}$ dimensional vector of exogenous variables that includes the leading indicators of

\footnotetext{
${ }^{15}$ See, Özler and Tabellini (1991), Cukierman et al. (1992), and Alesina et al. (1992) for positive association between political instability and external debt, inefficient tax system, and low growth. In fact, the literature on political economy approach to macroeconomic policy offers incisive observation on the persistence of budget deficits. In this regard, two concepts for the Russian experience are relevant. First of these concepts, as modelled by Alesina and Drazen (1991), is known as 'war of attrition'. A typical example to explain this phenomenon between conflicting political groups is an unsustainable budget deficit. The deficit is often demanding to close down due to lack of political agreement, which has to do with asymmetric information among key political figures; that is, who bears the cost of stabilisation. Thus, the higher the number of political parties in a legislative council, the higher the likelihood of conflict and the harder to reach agreements. Similarly, the second of these concepts 'political instability and deficit bias', as modelled by Alesina and Tabellini (1990), notes that alternating governments disagree over the composition of public spending that give rise to budget deficits. Typically, the unstable the political system, higher the political polarisation or the likelihood of a government change, the stronger the deficit bias. In effect, the delay in stabilisation stemming from politically instability may last until it becomes extremely costly; for example, in a currency crisis.

${ }^{16}$ To exploit the time series information to the maximum, initial idea was to estimate a model within the error correction framework. This methodology could not be used due to the stationarity of one dependent variable, exchange market pressure, and in the case of other dependent variable no cointegrating relationship was found that would be significant in the error correction model. The analysis then had to be restricted to the short run only.
}

${ }^{17}$ If the endogenous variable is integrating variable of order zero, that is I $(0)$, then it is not differenced. 
currency crises, which are selected on the basis of Russian experience and the seminal literature. $n$ lags of the variables describe the dynamics of the system. $\xi$ is the error term.

With two different dependent variables, the model is estimated twice: once with real effective exchange rate and once with exchange market pressure (a variable for measuring the speculative activity on a currency irrespective of exchange rate regime). In particular, we estimate the determinants of real effective exchange rate and exchange market pressure in line with our main hypothesis of political instability, the Russian experience discussed above, and the predictions of first- and secondgeneration models of currency crises. ${ }^{18}$

We use real effective exchange rate (REER) and exchange market pressure (EMP) as proxy to the pegged nominal exchange rate and therefore as dependent variables for estimation purposes. A common approach to measuring REER is based on the average of a common purchasing power parity relation vis-à-vis each trading partner country. However, we make no attempt to calculate it and take the series directly from International Financial Statistics database. Note that the increase in REER index amounts to its appreciation. Our objective is to find the determinants of REER in light of our discussion of the Russian crisis in the preceding section.

In calculating our second dependent variable, the EMP, we follow Weymark's (1995) method. In words of Weymark (p. 278): "Exchange market pressure measures the total excess demand for a currency in international markets as the exchange rate change that would have been required to remove this excess demand

\footnotetext{
${ }^{18}$ The reason for estimating the above model twice with two different dependent variables is to establish the robustness of political instability as the determinant of Russian crisis. Choosing real effective exchange rate and exchange market pressure as a proxy to Russian crisis, on the other hand, stems from two main problems that are often associated with estimating the crisis of a pegged exchange rate. First, if the exchange rate is restricted by some administrative regulation then modelling it is nearly impossible since the series does not exhibit any variance. The best determinant of a pegged nominal exchange rate would then be a constant. The artificiality of the series automatically excludes the possibility of the significance of other variables in the regression. Second, in the empirical content to the currency crises literature, the common approach to modelling currency crises seizes on methods based on probability analysis. While this method might be more relevant in a multi-country analysis, in a single-country case the weakness of this approach relates to the fact that the available sample would exhibit only one crisis period. In fact, this very much depends upon the definition of a crisis. By taking, for example, 20 percent depreciation of nominal exchange rate that happens only once in the sample could actually be interpreted as an outlier. It is then difficult to explain quantitatively events that were observed only once. Nonetheless, by using a proxy series to the pegged nominal exchange rate, such as real effective exchange rate or a variant of an indicator measuring the exchange rate market pressure could help overcome the first problem. The problem of outlier could be tackled by actually estimating the determinants of the aforementioned proxies.
} 
in the absence of exchange market intervention, given the expectations generated by the exchange rate policy actually implemented." In other words, exchange market pressure actually measures the size of the exchange rate change that would have occurred if the authorities unexpectedly refrain from intervening in the foreign exchange market. ${ }^{19}$ Irrespective of the exchange rate regime, negative values of EMP indicate a downward pressure (appreciation) on the exchange rate whereas positive values indicate upward pressure (depreciation) on the exchange rate and can be associated with a speculative attack. Therefore, our objective is to test for the variables that cause increase or decrease in this variable.

Based on our discussion before, the empirical part of the literature on currency crises, and data availability, the initial set of explanatory variables was large as there could be many potential determinants of currency crises. ${ }^{20}$ This study reports only those variables that proved to be significant in the estimated equations. As mentioned before, a crucial factor for the explanation of the Russian crisis is a proxy to the general political environment. Therefore, to illustrate the impact of political instability on dependent variables' behaviour, we use the probit estimation methodology to calculate the estimated frequencies of the probability of a change

Table 3. Variables Used in the Estimates of Equation (1)

\begin{tabular}{|c|c|c|c|}
\hline Variable & Type & Description & $\begin{array}{l}\text { Stationar- } \\
\text { ity Status }\end{array}$ \\
\hline$\overline{\mathrm{REER}}$ & Dependent & real effective exchange rate index & $\mathrm{I}(1)$ \\
\hline EMP & Dependent & exchange market pressure index & $\mathrm{I}(0)$ \\
\hline CHGOVT & Independent & political instability index (change in and of government) & $\mathrm{I}(0)$ \\
\hline RGDP & Independent & real gross domestic product & $\mathrm{I}(1)$ \\
\hline INFLT & Independent & CPI inflation & $\mathrm{I}(1)$ \\
\hline DC & Independent & domestic credit & I ( $(1)$ \\
\hline DC/RGDP & Independent & domestic credit to real gross domestic product & $\mathrm{I}(1)$ \\
\hline ED & Independent & External debt & $\mathrm{I}(0)$ \\
\hline OILP & Independent & Oil price; U.K. Brent, U.S. dollar/barrel & $\mathrm{I}(1)$ \\
\hline
\end{tabular}

\footnotetext{
${ }^{19}$ In Appendix B we detail the methodology and calculation of this variable. Exchange market pressure measures the excess demand/supply for/of foreign exchange reserves associated with exchange rate policy; or, the actual exchange rate change required by the degree of external imbalance and presence/ absence of speculative activity.
${ }^{20}$ Note that (fundamental) determinants of REER are more or less the same as of currency crises. See, for example, Montiel (1999a) and (1999b) for the determinants for real exchange rate and footnote 7 for a parsimonious list of the determinants of currency crises.

${ }^{21}$ See, Appendix $\mathrm{C}$ for detailed description of the methodology and results. 
in and of government (CHGOVT). ${ }^{21}$

This investigation is based on a quarterly sample from 1994:Q2 to 2001:Q4. Seasonally adjusted data were taken from the International Financial Statistics and the $O E C D$ databases. To establish the time series properties of all the variables used, we applied the Augmented Dickey-Fuller (ADF) test. For consistency in our short run model [Equation (1)], the non-stationary variables were transformed into stationary and logs of variables were taken. Table 3 summarizes all the variables used.

\section{Findings}

The model is estimated on both REER and EMP using general-to-specific approach; in both cases Equation (1) is estimated by using the ordinary least square method. The estimation of Equation (1) with REER as dependent variable produced the following results (with t-statistics in parentheses):

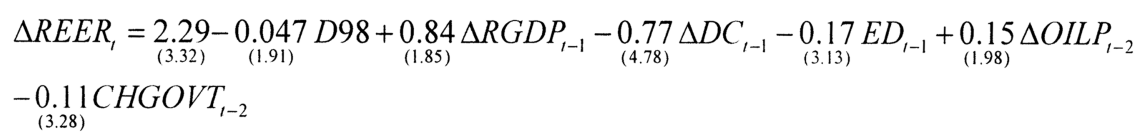

R-squared (adjusted): $0.71 \quad$ D-W statistic: 1.77

All variables are significant and signs of their parameters correspond to our assumptions. The obtained results suggest that growing real GDP causes real effective exchange rate to appreciate. Similarly, increasing oil price carry the same effect on the dependent variable. In effect, the positive association of both these variables reflects confidence in the Russian ruble.

On the other hand, the variables that undermined the confidence in ruble are domestic credit, external debt, and political instability. The former two variables, in fact, are representative of Russian fiscal imbalances. In effect, expanding domestic credit and increasing external debt results in the weakening of currency.

Political instability as reflected in the frequent changes in and of government with two lags enters the above estimated equation as highly significant. The coefficient of CHGOVT, the prime concern of this study, captures the effects of general political environment of Russia on the ruble REER. As shown, the negative association of this variable with REER implies that higher political instability reduces the confidence in currency. Thus, this confirms the importance of political factors as a determinant of Russian currency crisis.

The second version of Equation (1) with EMP as dependent variable produced 
the following results (with t-statistics in parentheses):

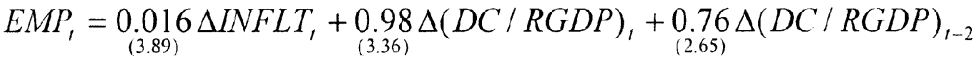

$$
\begin{aligned}
& +\underset{(2.34)}{0.57} \Delta O I L P_{t}-\underset{(2.11)}{0.56} \Delta O I L P_{t-2}+\underset{(2.15)}{0.11 C H G O V T_{t-1}}
\end{aligned}
$$

\section{R-squared (adjusted): 0.68 D-W statistic: 1.63}

Speculative activities on the Russian ruble therefore were driven by domestic inflation rate, ratio of domestic credit to real GDP, oil prices, and probability of changes in and of government.

With the exception of inflation rate, the determinants of speculative activity on Russian ruble are nearly the same as of the Russian REER in Equation (1a). While a negative coefficient of oil prices with two lags signify the strengthening of the demand for ruble, positive coefficients with the rest of explanatory variables indicate the weakening of the demand with their increase.

The variable for political instability, CHGOVT, enters with one lag in this estimate. The positive association of this variable with EMP index reflects that with the increase in political instability the speculations on ruble also increase. This is the second confirmation of political instability as the determinant of August 1998 Russian currency crisis.

\section{Concluding Remarks}

This study has argued that the political instability was an important factor behind the collapse of the Russian ruble in August 1998. Frequent changes in and of government undermined the implementation of much needed institutional and structural reforms. The reforms were highly crucial in achieving the monetary and fiscal targets consistent with the exchange rate based stabilisation programme launched in 1995. Inability to implement consistent and coherent policies to achieve, primarily, fiscal balances was an equally important determinant of Russian crisis. This inability stemmed from the continuous political instability that remained one of the main highlights of Russian transition in 1990s.

The empirical exercise undertaken in this study confirms this hypothesis. By

\footnotetext{
${ }^{22}$ The dummy for crisis year, $D 98$, was not significant in this estimate. Similarly, domestic credit in levels was also not significant and the estimate was done using the ratio of domestic credit to real gross domestic product.
} 
using real effective exchange rate and an index of exchange market pressure as a proxy to the Russian crisis, we estimate a general form of a short run model with more or less same set of explanatory variables. The estimates show that along with domestic credit (variable used to capture the effects of fiscal imbalances) and oil prices, political instability as signified in the frequent changes in and of government turns out to be highly significant in both regressions.

\section{Acknowledgements}

The authors are greatly indebted to an anonymous referee for very constructive comments. They wish to thank Safdar ullah Khan for helpful suggestions. Thanks are also due to DIW Berlin and the participants of its internal seminar. The corresponding author wishes to thank the Yrjö Jahnsson Foundation for financial support at the early stages of the project.

Received 8 December 2005, Accepted 28 June 2006 


\section{Appendix A: Changes in Government and Significant Events, Apr 1994 - Mar 2002}

\begin{tabular}{|c|c|c|}
\hline Month & Change in Government & Significant Event \\
\hline \multicolumn{3}{|c|}{1994} \\
\hline Aug & & $\begin{array}{l}\text { Russian grain market in crisis after Roskhlebo- } \\
\text { produkt (trading company responsible for buying } \\
\text { grains from farmers for authorities) does not get } \\
\text { the credit from the government. }\end{array}$ \\
\hline Sept & & $\begin{array}{l}\text { Ruble depreciates about } 19 \% \text { after a speculative } \\
\text { attack. }\end{array}$ \\
\hline Oct & $\begin{array}{l}\text { Dismissal of Acting Finance Minister. } \\
\text { Resignation of the Chairman of the } \\
\text { Russian Central Bank. } \\
\text { Economic Minister resigns. }\end{array}$ & $\begin{array}{l}\text { Ruble depreciates by } 28 \% \text {. } \\
\text { Vote of no confidence is narrowly escaped by Vik- } \\
\text { tor Chernomyrdin's government. } \\
\text { Russian fighter planes launch attacks against } \\
\text { Chechen rebels. }\end{array}$ \\
\hline \multicolumn{3}{|c|}{1995} \\
\hline June & $\begin{array}{l}\text { Resignation of Defence and } \\
\text { Interior Ministers }\end{array}$ & $\begin{array}{l}\text { Hostage crisis of Budyannovsk } \\
\text { Vote of no confidence against the government by } \\
\text { Duma }\end{array}$ \\
\hline July & & $\begin{array}{l}\text { President Boris Yeltsin admitted to hospital with } \\
\text { heart complaint }\end{array}$ \\
\hline Aug & & $\begin{array}{l}\text { Russian bank crises erupt due to illiquidity and } \\
\text { bad debts }\end{array}$ \\
\hline Sept & & $\begin{array}{l}\text { One day protest by teachers against low pay and } \\
\text { wage arrears }\end{array}$ \\
\hline Nov & $\begin{array}{l}\text { Acting Chairperson of the } \\
\text { Russian Central Bank is removed }\end{array}$ & $\begin{array}{l}\text { President Boris Yeltsin leaves hospital and enters } \\
\text { sanatorium }\end{array}$ \\
\hline \multicolumn{3}{|c|}{1996} \\
\hline Jan & $\begin{array}{l}\text { Foreign Minister and Deputy Prime } \\
\text { Minister are removed First Deputy } \\
\text { Prime Minister for Economic Policy resi }\end{array}$ & $\begin{array}{l}\text { Hostage Crisis in Kizlyar, Dagestan } \\
\text { s }\end{array}$ \\
\hline Feb & & Miners strike, $80 \%$ of mines were put out of action \\
\hline June & Defence Minister sacked & \\
\hline July & & $\begin{array}{l}\text { Hostilities recommence in Chechnya } \\
\text { Tveruniversalbank is put under crisis management } \\
\text { and later its license revoked }\end{array}$ \\
\hline Sep & & Hunger strike at Primorskii Power Plant \\
\hline Dec & & Coal miners launch strike \\
\hline \multicolumn{3}{|c|}{1997} \\
\hline Jan & & President Boris Yeltsin hospitalised \\
\hline March & Major cabinet reshuffle & $\begin{array}{l}\text { March } 27 \text { observed as national day of strikes } \\
\text { against wage arrears and social issues }\end{array}$ \\
\hline Apr & $\begin{array}{l}\text { Labour Minister resigns } \\
\text { Fuel and Energy Minister resigns } \\
\text { Head of State Tax Service resigns }\end{array}$ & \\
\hline May & $\begin{array}{l}\text { Dismissal of Deputy Defence Minister } \\
\text { Dismissal of Defence Minister }\end{array}$ & Miners strike in Primorskii \\
\hline
\end{tabular}






\section{Appendix A - continued}

\begin{tabular}{|c|c|c|}
\hline Month & Change in Government & Significant Event \\
\hline \multicolumn{3}{|c|}{1998} \\
\hline Mar & $\begin{array}{l}\text { Dismissal of Viktor Chernomyrdin as } \\
\text { Prime Minister }\end{array}$ & $\begin{array}{l}\text { President Boris Yeltsin falls ill with acute } \\
\text { throat infection }\end{array}$ \\
\hline Apr & $\begin{array}{l}\text { Appointment of Sergei Kiriyenko as } \\
\text { Prime Minister and appointment of new } \\
\text { cabinet takes place }\end{array}$ & \\
\hline May & & $\begin{array}{l}\text { Blockade of Trans-Siberian rail road by } \\
\text { miners }\end{array}$ \\
\hline & & $\begin{array}{l}\text { Director of the State Statistics Committee is } \\
\text { arrested }\end{array}$ \\
\hline June & & $\begin{array}{l}\text { Duma passes a bill stating that the external } \\
\text { debt of Russia has reached unsustainable } \\
\text { levels and threatens sovereignty }\end{array}$ \\
\hline July & & $\begin{array}{l}\text { Chairman of the State Duma Defence } \\
\text { Committee is shot }\end{array}$ \\
\hline Aug & \multirow{2}{*}{\multicolumn{2}{|c|}{$\begin{array}{l}\text { Dismissal of Prime Minister Sergei Kiriyenko C } \\
\text { and his cabinet } \\
\text { Viktor Chernomyrdin is reappointed Prime } \\
\text { Minister but Duma rejects the appointment } \\
\text { Chairman of the Central Bank of Russia } \\
\text { resigns Yevgeny Primakov is appointed Prime } \\
\text { Minister Head of Federal Tax Service is fired }\end{array}$}} \\
\hline Sept & & \\
\hline Oct & & $\begin{array}{l}\text { Nationwide strike } \\
\text { President Boris Yeltsin hospitalised with } \\
\text { pneumonia }\end{array}$ \\
\hline Dec & & Tekobank is declared bankrupt \\
\hline \multicolumn{3}{|c|}{1999} \\
\hline Apr & & $\begin{array}{l}\text { Chief coordinator of Liberal } \\
\text { Democratic Party is murdered }\end{array}$ \\
\hline May & $\begin{array}{l}\text { Prime Minister Yevgeny Primakov is sacked } \\
\text { Sergei Stepashin is appointed Prime Minister }\end{array}$ & $\begin{array}{l}\text { Impeachment initiative on President } \\
\text { Boris Yeltsin by Duma fails }\end{array}$ \\
\hline Aug & $\begin{array}{l}\text { Prime Minister Sergei Stepashin is dismissed } \\
\text { Vladimir Putin is appointed Prime Minister }\end{array}$ & $\begin{array}{l}\text { Unrest in Chechnya restarts } \\
\text { Bomb explosion in a shopping mall in Moscow }\end{array}$ \\
\hline Sept & & $\begin{array}{l}\text { Bomb explosion in South East Moscow, in } \\
\text { South Moscow, and in Volgodousk } \\
\text { Russian troops move into Chechnya }\end{array}$ \\
\hline
\end{tabular}


$\mathrm{Feb}$

Aug

Mar Reshuffling of the government
The Moscow arbitration court declares Inkombank bankrupt

Bomb explosion in Moscow

Sinking of Kursk

2001

No-confidence vote against prime minister Mikhail Kasyanov

March Head of the Central Bank resigns

Source: Russian Economic Trends, Russian-European Centre for Economic Policy, London: Whurr Publications (various years)

\section{Appendix B: Exchange Market Pressure}

The calculation of Exchange Market Pressure (EMP) draws from Weymark's (1995) in which EMP can be calculated as follows: $E M P_{t}=\Delta e_{t}+\eta \Delta r_{i}$. Where, $\Delta e_{t}$ is the change in nominal exchange rate, $\Delta r_{t}$ is the change in foreign exchange reserves, and $\eta=-\left[a_{2}+b_{2}\right]^{-1}$. Here, $a_{2}$ is the coefficient of nominal exchange rate in an equation that characterises domestic price responsive to foreign price and exchange rate variation; and $b_{2}$ is the coefficient of interest rate in a standard money demand equation. Implementing the aforementioned calculations, we first get the following estimates for the money demand and purchasing power parity equations, respectively (with t-statistics in parenthesis):

$$
M=\underset{(32.160)}{5.887}+\underset{(7.528)}{1.106} R G D P_{,}-\underset{(6.535)}{0.001 I N T_{l}} \quad P=\underset{(16.063)}{0.878 P^{*}}+\underset{(23.958)}{0.717} E_{l}
$$

R-squared (adjusted): 0.706Durbin-Watson: 1.061 R-squared (adjusted): 0.899 Durbin-Watson: 0.304

$M$ is the real money demand, $R G D P$ is the real GDP, INT are the lending interest rates, $P$ is the consumer price index, $P^{*}$ is the U.S. producer price index, and $E$ is the ruble to U.S. dollar nominal exchange rate. All the data is from International Financial Statistics and OECD databases.

After taking values of relevant parameters from the above estimates, we calculate the elasticity and then the exchange market pressure index. ${ }^{23}$

\section{Appendix C: Russian Political Instability}

We take the probability of unexpected changes in government as an indicator of Russian political instability by using the probit estimation methodology. The change

\footnotetext{
${ }^{23}$ Estimated values are available from the corresponding author on request.
} 
is limited to the firing, dismissal, removal, or replacement of Prime Ministers and Ministers for Foreign, Internal, Defence, Finance, Labour, and Fuel and Energy; this also includes the unexpected reshuffling within the government. Reshuffling within the government or the change in Prime Minister and aforementioned Ministries as a result of elections, however, is not unexpected and therefore is not considered. Removal or resignation of the heads of important institutions such as Central Bank and Federal or State Tax Services is also taken into account. Appendix A gives a detailed overview of these changes.

Applying the probit estimation method on quarterly data, the dependent variable, change in government (CHGOVT), equals one in that quarter when there was a change in government according to the above definition, zero otherwise. What affects CHGOVT? Intuitively, the variables that might explain variations in CHGOVT can fall into two broad categories of economic performance and political uncertainties variables.

Among economic performance, we suggest three variables: (i) Real Gross Domestic Product (RGDP): A higher level of real GDP would reflect overall health of the economy and thus general satisfaction with the government's economic performance. This would imply lesser likelihood of government change. (ii) Inflation (INFLT): A persistent and higher rate of inflation is a negative indicator of a government's performance. Therefore, higher inflation would mean higher likelihood of changes in the government; (iii) Real Wages (RW): A low level of real wages is an indicator of dissatisfaction from the government, especially when an economy is dominated by public sector. An increase in wages would imply lesser likelihood of change in the government.

Among political uncertainties, we suggest two dummy variables: (iv) Quarters (QRTS): This variable, first of the two political variables, is defined as the number of quarters from a previous change in the government. It is assumed that a greater number of quarters from previous change would imply a lesser likelihood of a change; (v) Significant Events (SEVNT): This is a dummy variable assuming a value of one in that quarter in which there is some development that indicates a direct or indirect affect on the government change, zero otherwise. Consider few examples in the case of Russia. Developments related to Chechnya: outbreak of conflict to peace negotiations to the restart of conflict; bouts of illnesses suffered by Boris Yeltsin, the President of Russian federation throughout the 1990s; strikes and riots; breaking of scandals; political murders; economic and financial crises. Thus, higher number of significant events would result in higher likelihood of govern- 
ment change. See, Appendix A for details.

In generating the political instability index, or the estimated frequencies of the probability of a government change, we estimate a probit model with CHGOVT as dependent variable and aforementioned economic performance and political uncertainties as explanatory variables. The data on RGDP and RW is from International Financial Statistics database and on INFLT is from OECD Statistics database over 1994:Q2 to 2001:Q4. In actual estimations, however, the dummy variables for capturing the effects of political uncertainties were not significant. Nonetheless, the probit model for the probability of government change due to economic performance only is given with the following results (t-statistics in parenthesis).

$$
C H G O V T_{1}=\underset{(2.04)}{-0.13} \Delta R G D P_{1-1}+\underset{(1.61)}{0.06} \Delta I N F L T_{1-3}-\underset{(2.39)}{0.33} \Delta R W_{1}+\underset{(1.98)}{0.16 \Delta R W_{1-2}}
$$

$\Delta$ signifies that the respective variables are differenced once. All the explanatory variables have a priori expected signs and are significant at 5 percent level. Estimated values of CHGOVT from the above regression are taken as the political instability (change in and of government) index. ${ }^{24}$

Received 8 December 2005, Accepted 28 June 2006

\section{References}

Alesina, A., S. Özler, N. Roubini, and P. Swagel (1992). Political Instability and Economic Growth. NBER Working Paper No. 4173. MIT, Massachusetts

Alesina, A. and A. Drazen (1991). Why are Stabilization Delayed? American Economic Review, 81, 1170-1188.

Alesina, A. and G Tabellini (1990). Voting on the Budget Deficit, American Economic Review 80, 37-49.

Antczak, R. (2001). The Russian Crisis of 1998, in M. Dabrowski (Ed.). The Episodes of Currency Crises in the European Transition Economies (Ed.) Dabrowski, CASE Report No. 40, Centre for Social and Economic Research. Warsaw, pp. 23-51

Balino, T., D. Hoelscher, and J. Horder (1997). Evolution of Monetary Policy Instruments in Russia, IMF Working Paper 80, IMF, Washington, D.C.

Blanco, H. and P. Garber (1986) Recurrent Devaluations and Speculative Attacks on the Mexican Peso, Journal of Political Economy 94, 148-166.

Cukierman, A., S. Edwards, and G. Tabellini (1992). "Seignorage and Political Instability."

${ }^{24}$ Estimated values are available from the corresponding author on request. 
American Economic Review 82, 537-556.

Cumby, R. and S. Van Wijnbergen (1989). Financial Policy and Speculative Runs with a Crawling Peg: Argentina, 1979-1981. Journal of International Economics 27, 111127.

Dabrowski, W., W. Paczynski, and L. Rawdanowicz (2001). Inflation and Monetary Policy in Russia: Transition Experience and Future Recommendations, RussianEuropean Centre for Economic Policy Working Paper, Russian-European Centre for Economic Policy, Moscow

Desai, P. (2000) Why Did the Ruble Collapse in August 1998? American Economic Review, 90, 48-52.

Esquivel, G. and F. Larrain B. (1998). Explaining Currency Crises, Mimeo, Harvard Institute for International Development, Massachusetts

Frankel, J. and A. Rose (1996). Currency Crashes in Emerging Markets: An Empirical Treatment, Journal of International Economics 41, 351-366.

Giannaros, D. (2000). Did the 'Shock Therapy' Approach Work in the Economic Restructuring of Eastern Europe? Some Evidence from Poland and Russia: A Brief Review." Global Business and Economic Review 2, 53-66.

Goldberg, L. (1994). "Predicting Exchange Rate Crises: Mexico Revisited." Journal of International Economics 36:413-430.

Granville, C. (2001). The Political and Societal Environment of Economic Policy, in Russia's Post-Communist Economy (Ed). Granville, B., Oppenheimer, P., Oxford University Press, Oxford, pp. 21-61

Kaminsky, G, S. Lizondo, and C. Reinhart (1998) Leading Indicators of Currency Crisis, Staff Papers (IMF) 45, 1-48.

Kharas, H., B. Pinto, and S. Ulatov (2001). An Analysis of Russia's 1998 Meltdown: Fundamentals and Market Signals, Brookings Papers on Economic Activity, 1, pp. 168

Klein, M. and N. Marion (1997) Explaining the Duration of Exchange Rate Pegs Journal of Development Economics, 54, 387-404.

Kounov, A. and A. Sitnikov (1999) The 'Constitutional Economy' of Russia: Political Roots of Economic Problems, Russian Economic trends, Vol. 8, No. 4. Russian European Centre for Economic Policy, Moscow

Krugman, P. (1979) A Model of Balance of Payments Crisis, Journal of Money, Credit, and Banking 11, 311-325.

Lamfalussy, A. (2000) Financial Crises in Emerging Markets: An Essay on Financial Globalisation and Fragility. London, Yale University Press.

Levin, M. and G. Satarov (2000) Corruption and Institutions in Russia, European Journal of Political Economy, 16, 113-132.

Masson, P. (1999) Contagion: Macroeconomic Models with Multiple Equilibria, Journal of International Money and Finance, 18, 587-602.

Montiel, P. (1999a) The Long-Run Equilibrium Real Exchange Rate: Conceptual Issues and Empirical Research in Exchange Rate Misalignment: Concepts and Measure- 
ment for Developing Countries (Ed.) Hinkle, L., Montiel, P., Oxford University Press, New York, pp. 219-263

Montiel, P. (1999b) Determinants of the Long-Run Equilibrium Real Exchange Rate: An Analytical Model, in Exchange Rate Misalignment: Concepts and Measurement for Developing Countries (Ed.) Hinkle, L., Montiel, P., Oxford University Press, New York, pp. 264-290

Obstfeld, M. (1986). Rational and Self-fulfilling Balance of Payments Crises, American Economic Review 76, 72-81.

Otker, I. and C. Pazrabaşioğlu (1997) Speculative Attacks and Macroeconomic Fundamentals: Evidence from Some European Currencies, European Economic Review, 41, 837-845.

Özler, S and G. Tabellini (1991). External Debt and Political Instability, NBER Working Paper No. 3772. NBER, Massachusetts

Pautola, N. (2000). Russia's External Debt, Solvency, and Options for Alternative Capital Inflow, Russian Economic Trends 9, 30-38.

Pazrabaşioğlu, C. and I. Otker (1997). Likelihood versus Timing of Speculative Attacks: A Case Study of Mexico, European Economic Review, 41, 837-845.

Poirot Jr., C. (2001). Financial Integration Under Conditions of Chaotic Hysteresis: The Russian Financial Crisis of 1998, Journal of Post Keynesian Economics, 23, 485507.

Rodrik, D. and A. Velasco (1999). Short-term Capital Flows, NBER Working Paper No. 7364, Massachusetts

Summers, L. (2001) Comment on Kharas et al., Brookings Papers on Economic Activity, 1. pp. $51-57$

Weymark, D. (1995) Estimating Exchange Market Pressure and the Degree of Exchange Market Intervention for Canada, Journal of International Economics 39, 273-295. 